\title{
APLIKASI TRACKING DISPOSISI SURAT DI POLITEKNIK NEGERI SRIWIJAYA BERBASIS ANDROID WEBVIEW
}

\author{
Indra Satriadi ${ }^{1}$, Sony Oktapriandi ${ }^{2}$, Hetty Meileni ${ }^{3}$, Desi Aprianty ${ }^{4}$ \\ ${ }^{1,2,3,4}$ Manajemen Informatika, Politeknik Negeri Sriwijaya \\ Jl. Srijaya Negara, Bukit Lama, Bukit Besar, Kota Palembang, Sumatera Selatan 30139 \\ E-Mail : ${ }^{1}$ sony.oktapriandi@gmail.com, ${ }^{2}$ hettymeileni@yahoo.co.id, \\ ${ }^{3}$ desi.aprianty@gmail.com
}

\begin{abstract}
Abstrak
Disposisi surat merupakan bagian yang tidak terpisahkan dalam kegiatan operasional suatu organisasi. Salah satu upaya dalam meningkatkan efektifitas komunikasi surat tersebut adalah dengan menggunakan Teknologi Informasi dan Komunikasi (TIK). Penelitian ini berfokus pada pembuatan aplikasi yang memudahkan pengguna dalam melakukan monitoring disposisi surat dari dan ke pimpinan di lingkungan Politeknik Negeri Sriwijaya. Tahapan penelitian dilakukan dengan melakukan inisiasi penelitian dengan menetapkan latar belakang, permasalahan, ruang lingkup dan fokus pembahasan penelitian. Pengumpulan data dilakukan melalui Observasi, Wawancara dan Studi Dokumen. Tahapan berikutnya adalah dengan melakukan analisis sistem yang terdiri dari Analisis Permasalahan, analisis Sistem yang berjalan dan Analisis Sistem Usulan. Perancangan menggunakan metode terstruktur dengan menggunakan diagram konteks, Data Flow Diagram (DFD), Entity Relationship Diagram (ERD). Implementasi Sistem dengan bahasa pemrograman PHP dan basis data MYSQL. Hasil akhir dari penelitian ini berupa aplikasi Tracking Disposisi Surat berbasis Android Webview
\end{abstract}

Kata Kunci - Disposisi Surat, Aplikasi Komputer, Android Webview

\section{Abstract}

Letter disposition is an integral part of the operational activities of an organization. One of the efforts to increase the effectiveness of the letter communication is to use Information and Communication Technology (ICT). This study focuses on making applications that make it easier for users to monitor the disposition of letters from and to leaders in the Sriwijaya State Polytechnic environment. The research stage was carried out by initiating research by determining the background, problems, scope and focus of research discussion. Data collection was carried out through observation, interview and document study. The next stage is to perform a system analysis consisting of Problem Analysis, running system analysis and Proposed System Analysis. The design uses a structured method using context diagrams, Data Flow Diagrams (DFD), Entity Relationship Diagrams (ERD). System implementation with the PHP programming language and MYSQL database. The final result of this research is an application of Tracking Letter Disposition based on Android Webview

Keywords - CIO, User Satisfaction, Information System Management

\section{PENDAHULUAN}

\subsection{Latar Belakang Surat merupakan alat}

komunikasi penyampaian informasi secara tertulis dari satu pihak ke pihak yang lain [1]. Surat berfungsi sebagai alat informasi tertulis mengenai suatu 
JURNAL NUANSA INFORMATIKA

Volume 15 Nomor 1, Januari 2021
p-ISSN : 1858-3911, e-ISSN : 2614-5405

https://journal.uniku.ac.id/index.php/ilkom hal tertentu secara jelas, tertulis dan harus terinci. Informasi yang disampaikan dapat berupa pemberitahuan, pernyataan, laporan, sanggahan, kritik dan sebagainya. Surat harus ditulis dengan menggunakan bahasa yang mudah dimengerti, serta jelas mengenai maksud dan tujuannya. Disposisi surat menjadi kegiatan opsional setelah pendistribusian surat, dimana langkah-langkah pendistribusian surat adalah menyampaikan surat-surat ke alamat yang dituju [2], mengklasifikasikan surat dengan menyusun berdasarkan tingkat kepentingannya dan menentukan pejabat mana yang harus menangani surat dengan menyertakan lembar disposisi. Pada Politeknik Negeri Sriwijaya surat salah satu media komunikasi yang sangat penting, baik untuk komunikasi dengan pihak luar atau pihak dalam organisasi yang bertuju kepada pimpinan Politeknik Negeri Sriwijaya. Sehingga diperlukan sistem terkomputerisasi yang mengakomodir dalam pendataan surat [3].

Monitoring disposisi surat adalah memastikan agar penyampaian surat berjalan sesuai rencana kepada surat yang dituju, aplikasi ini akan dibuat menggunakan android webview [4]. Android webview merupakan aplikasi android yang dapat menampilkan halaman website tanpa harus membuka web browser [9]-[10].

Beberapa instansi pemerintah sudah menerapkan digitalisasi dalam memonitoring atau tracking disposisi surat. Tracking disposisi secara digital sangat penting dilakukan mengingat kemudahannya dalam memonitoring posisi disposisi surat, dimana sekretaris atau admin instansi tidak perlu lagi keluar masuk ke ruang pimpinan untuk menyerahkan disposisi surat, terlebih jika ada masalah surat yang tidak terbaca, surat selip, surat hilang atau masalah lainnya.

Penelitian ini dilatarbelakangi pada proses disposisi surat khususnya di Politeknik Negeri Sriwijaya yang belum menerapkan sistem yang terkomputerisasi. Dalam proses pengarsipan surat maupun pendisposisian surat, perekaman data masih menggunakan pencatatan manual maupun pencatatan dengan menggunakan aplikasi spreadsheet. Hal ini dapat menimbulkan potensi permasalahan seperti keterlambatan dalam mengeksekusi surat dikarenakan surat hilang, surat tercecer maupun pimpinan tidak berada di tempat untuk jangka waktu yang lama. Sehingga diperlukan digitalisasi dalam tracking disposisi surat, yang menyimpan seluruh data surat ke dalam database yang dapat diakses langsung oleh pimpinan. Harapannya dengan adanya aplikasi ini dapat meningkatkan efisiensi dalam proses pendisposisian surat, juga dengan memudahkan user dalam melakukan interaksi sistem sesuai preferensi user itu sendiri [7]

Berdasarkan permasalahan di atas maka penulis membuat judul penelitian yang diajukan adalah Aplikasi Tracking Disposisi Surat di Politeknik Negeri Sriwijaya berbasis Android Webview yang diharapkan membantu dalam memonitoring disposisi surat dari dan ke Pimpinan Politeknik Negeri Sriwijaya

\subsection{Identifikasi Masalah}

Berdasarkan uraian latar belakang sebelumnya, identifikasi permasalahan dalam penelitian ini adalah :

a. Belum adanya sistem yang terkomputerisasi yang memonitoring dalam proses disposisi surat di Politeknik Negeri Sriwijaya

b. Potensi kendala terhambatnya 
JURNAL NUANSA INFORMATIKA

Volume 15 Nomor 1, Januari 2021

disposisi surat karena beberapa hal antara lain, surat tercecer, surat hilang maupun pimpinan tidak ada ditempat.

c. Belum adanya pendokumentasian disposisi surat secara terkomputerisasi di lingkungan Politeknik Negeri Sriwijaya.

\subsection{Tujuan Penelitian}

Adapun tujuan dari penelitian ini adalah:

a. Membuat sistem monitoring disposisi surat yang memudahkan pimpinan Politeknik Negeri Sriwijaya untuk memonitoring surat

b. Mempermudah proses disposisi surat dengan menerapkan sistem yang terkomputerisasi berbasis Android webview

c. Mempermudah dalam pendokumentasian disposisi surat secara terkomputerisasi di lingkungan Politeknik Negeri Sriwijaya

\subsection{Ruang Lingkup} ini meliputi:

Ruang Lingkup dalam penelitian

a. Penelitian ini berfokus pada monitoring disposisi surat dari dan ke pimpinan di lingkungan Politeknik Negeri Sriwijaya

b. Perancangan sistem dan pemodelan data dilakukan dengan perancangan terstruktur dengan pemodelan diagram konteks, data flow diagram, entity relationship diagram

c. Implementasi sistem menggunakan tools Sublime Text Editor, Android WebView, database MySQL, bahasa pemrograman web (PHP, HTML, CSS, dan Javascript)

d. Pengujian sistem dilakukan dengan melihat aspek fungsional dari sistem yang dihasilkan menggunakan metode Blackbox Testing
p-ISSN : 1858-3911, e-ISSN : 2614-5405

https://journal.uniku.ac.id/index.php/ilkom

\section{METODE PENELITIAN}

Metode Penelitian dapat dilihat pada gambar 1 di bawah ini:

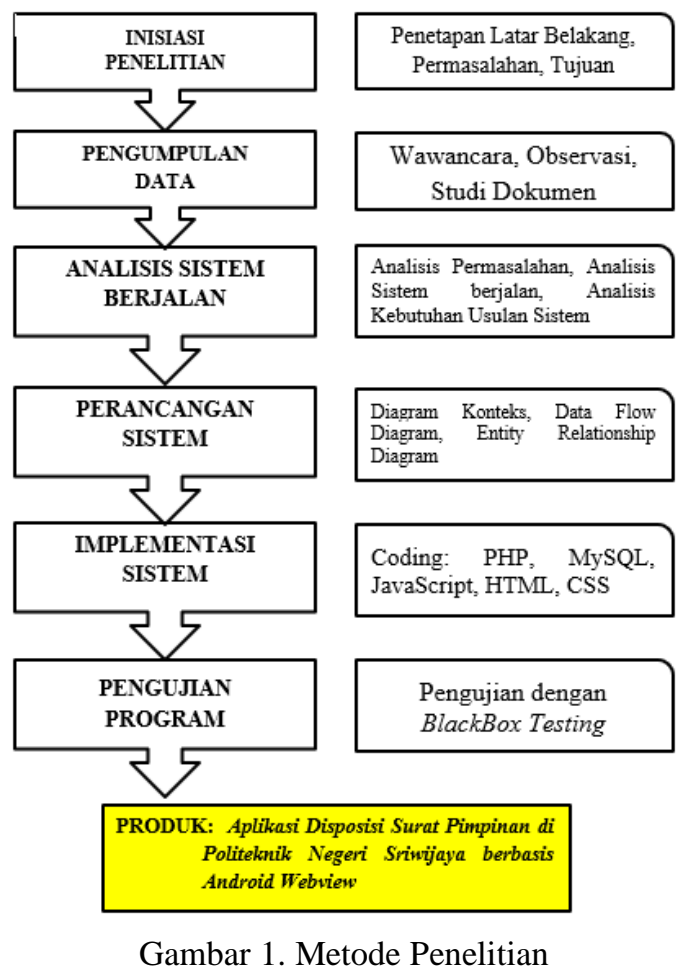

\subsection{Inisiasi Penelitian}

Merupakan tahapan awal, dimana pada tahapan ini ditentukan apa yang melatarbelakangi penelitian, pengemukakan dan perumusan masalah, serta tujuan permasalahan. Penelitian dilakukan di Politeknik Negeri Sriwijaya dengan fokus dalam pembuatan aplikasi tracking disposisi surat.

\subsection{Pengumpulan Data}

Pengumpulan data dilakukan dengan 3 cara yakni Observasi, Wawancara dan Studi Dokumen

\section{a. Observasi}

Peneliti melakukan pengamatan langsung bagaimana proses pendisposisian surat dari dan ke Pimpinan di Lingkungan Politeknik Negeri Sriwijaya. Dalam hal ini, peneliti juga melihat bagaimana pendokementasian dilakukan oleh 
JURNAL NUANSA INFORMATIKA

Volume 15 Nomor 1, Januari 2021

pengadministrasi

b. Wawancara

Setelah melakukan pengamatan langsung, peneliti melakukan wawancara dengan pihak-pihak terkait dalam proses disposisi surat. Wawancara dilakukan untuk mendalami permasalahan lebih lanjut, adapun pihak-pihak yang dilibatkan dalam wawancara adalah staf administrasi

c. Studi Dokumen

Studi Dokumen dilakukan dengan melihat dokumen-dokumen apa saja yang dibutuhkan dalam pendisposisian surat di Lingkungan Politeknik Negeri Sriwijaya seperti SOP, rekapitulasi surat masuk, rekapitulasi surat keluar

\subsection{Analisis Sistem Berjalan}

Analisis Sistem melihat dari beberapa aspek yakni analisis permasalahan, analisis sistem yang berjalan dan analisis Sistem yang diusulkan. Dalam analisis permasalahan, dilakukan dengan melihat permasalahan dan bagaimana pemecahan permasalahan tersebut [3]. Analisis Sistem yang berjalan melihat bagaimana sistem yang sudah ada, bagaimana proses pendisposisian surat secara manual. Analisis sistem berjalan direpresentasikan dengan diagram alir atau diagram kerja (workflow diagram) [4]. Sedangkan dalam Analisis Sistem Usulan melihat dari 2 aspek, yakni Analisis Kebutuhan Fungsional dan Analisis Kebutuhan Non Fungsional [5]:

a. Analisis Kebutuhan Fungsional

Dilakukan dengan melihat apa saja kebutuhan fungsional secara sistem seperti prosedur-prosedur apa saja terkait dengan perancangan aplikasi secara teknis

b. Analisis Kebutuhan Non Fungsional Melihat apa saja kebutuhan non
p-ISSN : 1858-3911, e-ISSN : 2614-5405

https://journal.uniku.ac.id/index.php/ilkom

fungsional, seperti spesifikasi perangkat lunak yang dibutuhkan, perangkat keras dan jaringan dalam mendukung dalam implementasi aplikasi tracking disposisi surat

2.4. Perancangan Sistem

Perancangan sistem menggunakan perancangan terstruktur dengan menggunakan Diagram Konteks, Data Flow Diagram (DFD), Entity Relationshio Diagram (ERD), Perancangan Basis Data, Perancangan Tampilan Antarmuka pengguna, pseudocode dan Kamus Data

\subsection{Implementasi Sistem}

Dalam tahapan ini merupakan pengkodean dimana hasil dari perancangan pada tahapan sebelumnya diimplementasikan dalam bahasa pemrograman. Tools dan bahasa pemrograman dalam implementasi sistem adalah PHP, HTML, CSS, Javascript, MySQL dan Sublime Text Editor

\subsection{Pengujian Program}

Dalam tahapan ini pengujian program menggunakan Blackbox Testing dimana menguji aspek fungsional dari program. Pengujian program dilakukan dengan membuat skenario pengujian lalu diujikan kepada sistem tersebut untuk dilihat apakah scenario tersebut berhasil atau tidak.

\section{HASIL DAN PEMBAHASAN}

\subsection{Analisis Kebutuhan}

Analisis kebutuhan merupakan tahapan ke tiga dari metode fast, tahapan ini dilakukan pengurutan prioritas dari kebutuhan- kebutuhan sistem yang sudah dibuat. Tujuan dari tahapan ini adalah mengidentifikasi data, proses dan antarmuka yang diinginkan pengguna dari sistem yang baru [6]. Analisis kebutuhan terdiri dari 
JURNAL NUANSA INFORMATIKA

Volume 15 Nomor 1, Januari 2021

kebutuhan fungsional dan non fungsional.

a. Kebutuhan Fungsional

Kebutuhan fungsional dari aplikasi yang akan dibangun adalah sebagai berikut:

1. Sistem website dan aplikasi dapat melakukan otoritas dan otentifikasi penggunanya seperti admin, humas, pimpinan, dan divisi.

2. Sistem website dan aplikasi dapat melakukan input data surat masuk, kirim surat, melihat list surat,dan melihat status surat.

b. Kebutuhan Non-Fungsional

Kebutuhan Non-Fungsional adalah kebutuhan tambahan yang tidak memiliki input, proses, dan output. namun kebutuhan nonfungsional ini sebaiknya dipenuhi karena akan sangat menentukan apakah sistem ini akan digunakan user atau tidak [8]. Kebutuhan nonfungsional ini dapat dikategorikan berdasarkan:

1. Operasional

- Website harus dapat diakses dengan browser.

- Website harus dapat diakses oleh pengguna yang dirumuskan.

\section{Keamanan}

Sistem website maupun database dilengkapi password, sehingga hanya user yang terdaftar yang dapat mengakses website

\subsection{Diagram Konteks}

Berikut ini diagram konteks dari penelitian yang dirancang:
p-ISSN : 1858-3911, e-ISSN : 2614-5405

https://journal.uniku.ac.id/index.php/ilkom

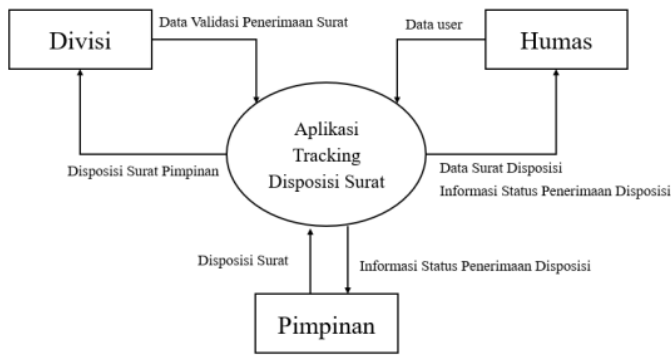

Gambar 2. Diagram Konteks

\subsection{Data Flow Diagram}

Untuk mempermudah dalam menggambarkan proses dan aliran data dari input menjadi output, maka diperlukan Data Flow Diagram yang dirancang sebagai berikut:

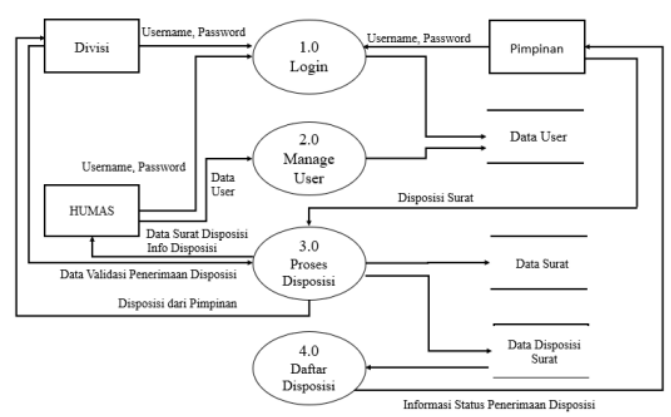

Gambar 3. Data Flow Diagram

Even List :

a. Admin melakukan Login dan masuk ke dalam sistem

b. Setelah masuk ke dalam sistem, admin dapat menginput data pengguna, melihat list surat, dan melihat status surat.

c. Humas melakukan Login dan masuk ke dalam sistem

d. Setelah masuk ke dalam sistem, humas dapat menginput surat dari luar politeknik negeri sriwijaya, mengirim surat ke pengguna lain, melakukan disposisi surat, melihat list surat dan melihat status surat.

e. Pimpinan dan Divisi melakukan Login dan masuk ke dalam aplikasi

f. Setelah masuk ke dalam sistem, pimpinan dan divisi dapat mengirim surat ke pengguna lain, melakukan disposisi surat, melihat 
JURNAL NUANSA INFORMATIKA

Volume 15 Nomor 1, Januari 2021

list surat dan melihat status surat.

\subsection{Entity Relationship Diagram}

Berikut merupakan rancangan dari ERD dalam aplikasi ini:

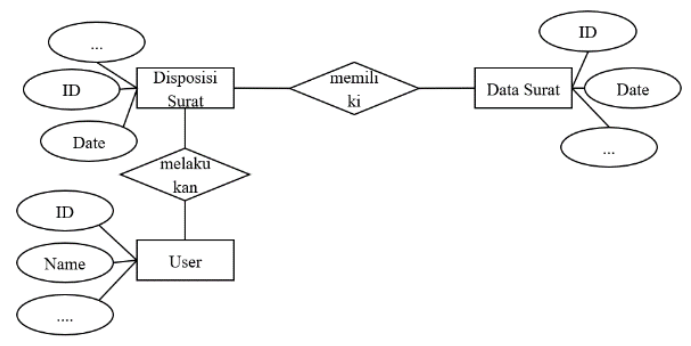

Gambar 4. Entity Relationship Diagram

\subsection{Rancangan Basis Data}

Rancangan basis data merupakan rancangan lanjutan dari ERD yang sudah dibuat sebelumnya. Terdapat 3 Tabel dalam basis data yang dirancang, yakni:

Tabel 1. Tabel Data Pengguna

\begin{tabular}{|l|l|l|l|l|}
\hline No & Field & Type & Size & Ket \\
\hline 1. & id_penerima & int & 11 & P.Key \\
\hline 2. & id_surat & int & 11 & \\
\hline 3. & nip & varchar & 20 & \\
\hline 4. & waktu_terima & varchar & 30 & \\
\hline
\end{tabular}

Tabel 2. Tabel Data Pengguna

\begin{tabular}{|l|l|l|l|l|}
\hline No & Field & Type & Size & Ket \\
\hline 1. & nip & varchar & 20 & P.Key \\
\hline 2. & password & varchar & 60 & \\
\hline 3. & nama & varchar & 30 & \\
\hline 4. & akses & varchar & 30 & \\
\hline
\end{tabular}

Tabel 3. Tabel Data Surat

\begin{tabular}{|l|l|l|l|l|}
\hline No & Field & Type & Size & Ket \\
\hline 1. & id_surat & int & 11 & P.Key \\
\hline 2. & no_surat & varchar & 10 & \\
\hline
\end{tabular}

p-ISSN : 1858-3911, e-ISSN : 2614-5405

https://journal.uniku.ac.id/index.php/ilkom

\begin{tabular}{|l|l|l|l|l|}
\hline 3. & tanggal & date & - & \\
\hline 4. & jenis & enum & - & \\
\hline 5. & hal & varchar & 100 & \\
\hline 6. & dari & varchar & 30 & \\
\hline 7. & kepada & varchar & 30 & \\
\hline 8. & sifat & varchar & 30 & \\
\hline 9. & waktu & timestamp & - & \\
\hline 10. & dokumen & varchar & 255 & \\
\hline 11. & isi_disposisi & text & - & \\
\hline 12. & tanggapan & text & - & \\
\hline
\end{tabular}

\subsection{Rancangan Tampilan Antar Muka Pengguna}

Berikut rancangan tampilan antar muka pengguna dari aplikasi yang dirancang:

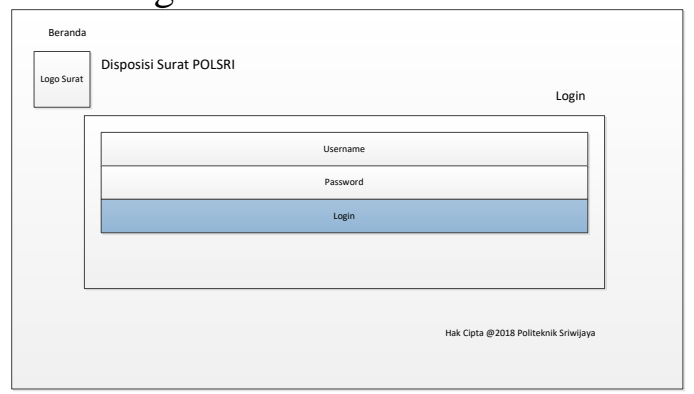

Gambar 4. Rancangan Form Login

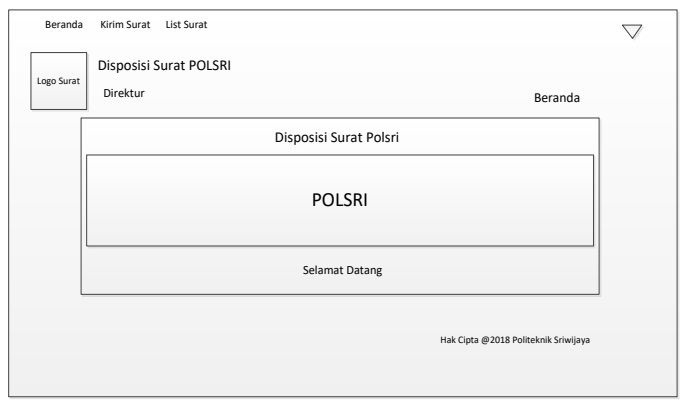

Gambar 5. Rancangan Form Menu Utama 
JURNAL NUANSA INFORMATIKA

Volume 15 Nomor 1, Januari 2021

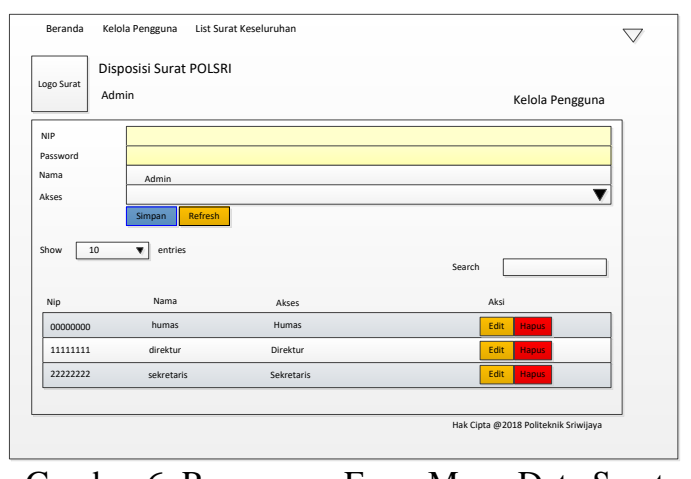

Gambar 6. Rancangan Form Menu Data Surat

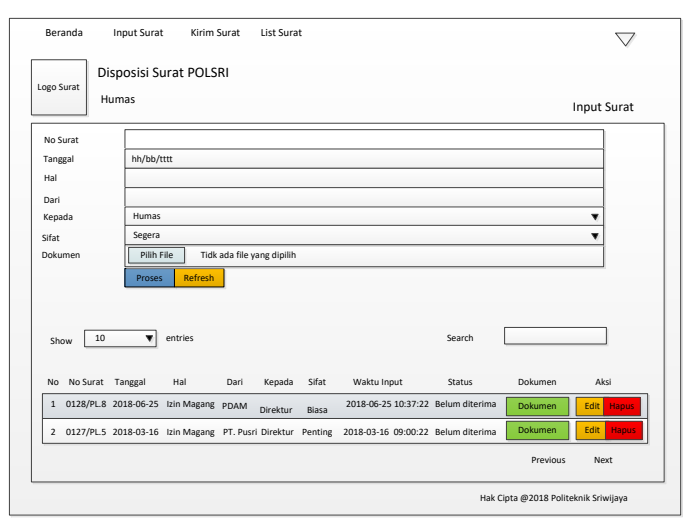

Gambar 7. Rancangan Form Menu Disposisi Surat

\subsection{Tampilan Antar Muka Pengguna}

Implementasi sistem dengan menggunakan pemrograman berbasis web seperti HTML, CSS, PHP dan Javascript. Sedangkan tools basis data yang digunakan adalah MySQL. Berikut tampilan antarmuka pengguna dari aplikasi yang dirancang:

\subsection{Pengujian Program}

p-ISSN : 1858-3911, e-ISSN : 2614-5405

https://journal.uniku.ac.id/index.php/ilkom

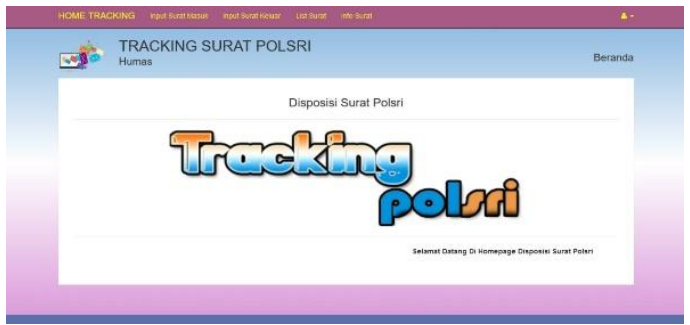

Gambar 8. Tampilan Form Menu Disposisi Surat

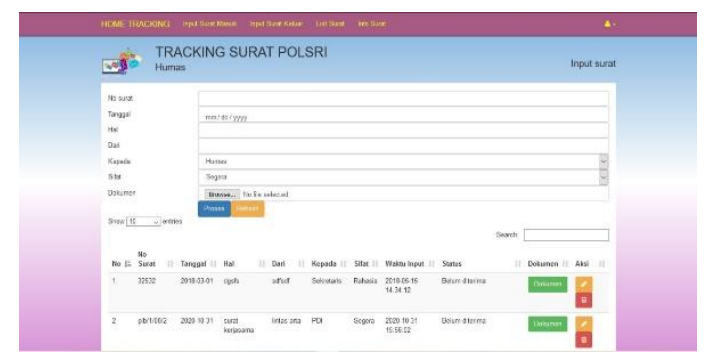

Gambar 9. Tampilan Form Menu Disposisi Surat

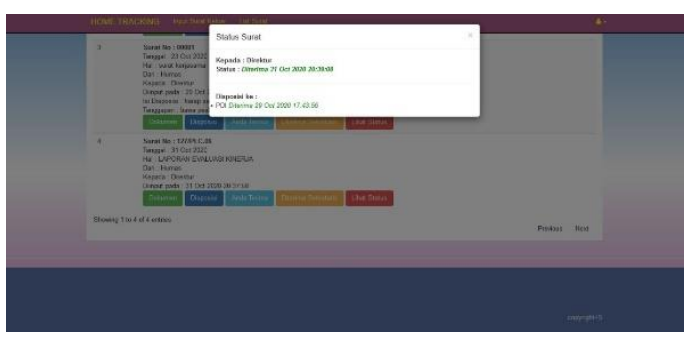

Gambar 10. Tampilan Form Menu Disposisi Surat

\begin{tabular}{|c|c|c|c|c|}
\hline No & Fitur & Skenario Uji & $\begin{array}{c}\text { Hasil yang di } \\
\text { harapkan }\end{array}$ & $\begin{array}{c}\text { Hasil } \\
\text { pengujian }\end{array}$ \\
\hline 1. & $\begin{array}{l}\text { Halaman } \\
\text { Login }\end{array}$ & $\begin{array}{l}\text { Memasukkan } \text { username dan } \\
\text { password dari pengguna dengan } \\
\text { akses admin }\end{array}$ & Login sebagai admin & $\begin{array}{l}{[\mathrm{x}] \text { diterima }} \\
{[] \text { ditolak }}\end{array}$ \\
\hline 2. & $\begin{array}{l}\text { Halaman } \\
\text { Kelola } \\
\text { Pengguna }\end{array}$ & $\begin{array}{l}\text { Menambah, } \\
\text { menghapus, dan melihat data } \\
\text { pengguna. }\end{array}$ & 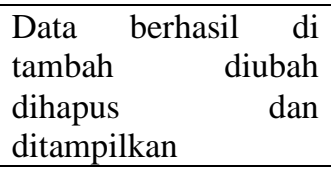 & $\begin{array}{l}\text { [x] diterima } \\
\text { [ ] ditolak }\end{array}$ \\
\hline 3. & $\begin{array}{l}\text { Halaman } \\
\text { Kirim Surat }\end{array}$ & $\begin{array}{l}\text { Menginput data surat yang ingin } \\
\text { dikirimkan kepengguna lain }\end{array}$ & $\begin{array}{l}\text { Data surat berhasil } \\
\text { diinput }\end{array}$ & $\begin{array}{l}\text { [x] diterima } \\
{[\text { ] ditolak }}\end{array}$ \\
\hline 4. & $\begin{array}{l}\text { Halaman } \\
\text { List Surat }\end{array}$ & $\begin{array}{lll}\text { Melihat data surat yang } \\
\text { dikirimkan ke pengguna }\end{array}$ & $\begin{array}{l}\text { Data surat di } \\
\text { tampilkan }\end{array}$ & $\begin{array}{l}\text { [x] diterima } \\
\text { [ ] ditolak }\end{array}$ \\
\hline
\end{tabular}




\begin{tabular}{|c|l|l|l|l|}
\hline No & \multicolumn{1}{|c|}{ Fitur } & \multicolumn{1}{|c|}{ Skenario Uji } & \multicolumn{1}{|c|}{$\begin{array}{c}\text { Hasil yang di } \\
\text { harapkan }\end{array}$} & \multicolumn{1}{c|}{$\begin{array}{c}\text { Hasil } \\
\text { pengujian }\end{array}$} \\
\hline 5. & Lihat Status & $\begin{array}{l}\text { Melihat status setiap penerima } \\
\text { dari surat }\end{array}$ & $\begin{array}{l}\text { Menampilkan status } \\
\text { dari penerima surat. }\end{array}$ & $\begin{array}{l}\text { [x] diterima } \\
\text { [ ] ditolak }\end{array}$ \\
\hline 6. & $\begin{array}{l}\text { Disposisi } \\
\text { Surat }\end{array}$ & $\begin{array}{l}\text { Melakukan disposisi dari surat } \\
\text { yang diterima }\end{array}$ & $\begin{array}{l}\text { Surat didisposisikan } \\
\text { setiap pengguna yang } \\
\text { dipilih }\end{array}$ & $\begin{array}{l}\text { [x] diterima } \\
\text { [ ] ditolak }\end{array}$ \\
\hline
\end{tabular}

\section{KESIMPULAN}

Secara garis besar kesimpulan dari penelitian ini adalah :

a. Sistem monitoring jalannya disposisi surat pimpinan Politeknik Negeri Sriwijaya ini digunakan untuk memberikan informasi mengenai alur surat disposisi pimpinan agar dapat dilihat secara web dan mobile.

b. Sistem ini dibuat dengan menggunakan android webview dan menerapkan metode fast sebagai cara untuk membuat sistem tersebut.

Sebagai saran untuk pengembangan ke depannya dalam penelitian ini adalah:

a. Untuk pengembangan lebih lanjut, aplikasi ini bisa dikembangkan lagi dengan fitur-fitur yang dapat menunjang jalannya sistem dikemudian hari.

b. Untuk segi keamanan data, kiranya perlu ditingkatkan lagi mengenai akses server ketika surat/dokumen di scan.

\section{DAFTAR PUSTAKA}

[1] Aji, Sapto., Migunani., Fitro Nur Hakim. (2014). Rancang Bangun Sistem Informasi Disposisi Surat Berbasis Web (Studi Kasus Kementerian Pekerjaan Umum). STMIK provinsi Semarang.

[2] Sunoto, Imam. (2015). Perancangan Sistem Informasi Administrasi Akademik Berbasis Web. Universitas Indraprasta PGRI.

[3] Sukamto, Rosa A dan M. Shalaludin. (2013). Rekayasa
Perangkat Lunak. Informatika :Bandung.

[4] Pratiwi, Sri Ambar., I Made Sukarsa,. I Ketut Adi Purnawan. (2014). Rancang Bangun Aplikasi Sistem Pemesanan Bunga Berbasis Android. Universitas Udayana.

[5] Fitriyani, Fifit. (2017). Penerapan Standars Operating Procedures (SOP) Pada Pelayanan Sirkulasi di Perpustakaan Fakultas Hukum UPN Veteran Jakarta. Universitas Islam Negeri Syarif Hidayatullah.

[6] Widiastuti, Nelly Indriani., Rani Susanto. (2014). Kajian Sistem Monitoring Dokumen Akreditasi Teknik Informatika Unikom. Universitas Komputer Indonesia.

[7] I. G. T. Isa. (2018). Kansei Engineering Approach in Software Interface Design. J. Sci. Innovare. vol. 1. no. 01. pp. 22-26.doi: 10.33751/jsi.v1i01.680.

[8] H. Purnaweni and Riwayatiningsih. (2017). Pemanfaatan Sistem Informasi Geografi dalam Pengembangan Pariwisata Geographic Information System Utilization in Tourism Development. Proceeding Biol. Educ. Conf., vol. 14, pp. 154-161

[9] Triwibowo, Dodi., Rinta Kridalukmana,. Kurniawan Teguh Martono. (2015). Pembuatan Aplikasi 
JURNAL NUANSA INFORMATIKA

Volume 15 Nomor 1, Januari 2021
p-ISSN : 1858-3911, e-ISSN : 2614-5405

https://journal.uniku.ac.id/index.php/ilkom

Terintegrasi, Pendataan Barang di Gudang Berbasis Android. Universitas Diponegoro.

[10] Pratiwi, Sri Ambar., I Made Sukarsa,. I Ketut Adi Purnawan. (2014). Rancang Bangun Aplikasi Sistem Pemesanan Bunga Berbasis Android. Universitas Udayana. 